\title{
DETERMINATION OF GABAPENTIN IN BULK DRUG AND IN PHARMACEUTICAL DOSAGE FORM BY HPLC METHOD
}

\author{
B. UDAYKUMAR RAO ${ }^{b}$ F. MAQDOOM ${ }^{b}$ AND ANNA PRATIMA NIKALJE ${ }^{a *}$
}

\author{
${ }^{a}$ Y.B. Chavan College Of Pharmacy, Dr. Rafiq Zakaria Campus, Rauza Bagh, Aurangabad, M.S. India \\ ${ }^{b}$ Maulana Azad Postgraduate and Research Center, Dr. Rafiq Zakaria Campus, Rauza Bagh, Aurangabad, M.S. India
}

(Received: March 24, 2009 - Accepted: August 23, 2009)

\begin{abstract}
This paper describes validation of the selective, precise and accurate isocratic HPLC method for the assay of Gabapentin as bulk and pharmaceutical dosage forms. The mobile phase composition was ammonium dihydrogen orthophosphate buffer and methanol in 60:40(v/v) proportions Column used was strong cation exchange column bonded with phenyl sulphonic acid. Quantitation was achieved by UV detection at $200 \mathrm{~nm}$. A linear response ( $\left.\mathrm{r}^{2} \geq 0.999\right)$ was observed in the range of $2.5 \mathrm{mg} / \mathrm{mL}-7.5 \mathrm{mg} / \mathrm{mL}$. The method shows good recoveries (Average 101.2\%) and the relative standard deviation intra and inter-day were found to be less than $0.5 \%$. Validation parameters were also determined. The method can be used for quality control assay of Gabapentin as bulk and in finished dosage form and for the stability studies as the method separates Gabapentin from its degradation products and excipients
\end{abstract}

Key words: Gabapentin HPLC Dosage form Method Validation.

\section{INTRODUCTION}

Gabapentin is 1-(aminomethyl)-cyclohexaneacetic acid (Fig 1) used in the treatment of epilepsy. Presently Gabapentin is widely used as a medication to relieve pain, especially neuropathic pain. Gabapentin increases GABA levels in the brain clinically. Even though exact mechanism of action is unknown, but its therapeutic action on neuropathic pain is thought that Gabapentin inhibits calcium influx by inhibiting calcium channels in presynaptic terminals. ${ }^{1-3}$

Literature survey reveals that several methods have been reported for quantitative determination of Gabapentin in human plasma or serum. ${ }^{4-8}$. Methods for the analysis of Gabapentin in pharmaceutical dosage form are limited and most of the available methods are involved derivetization step. ${ }^{9-12}$ Many of the proposed methods have some limitations such as long run time or using special reaction condition which may not be suitable for routine analysis. Few methods are reported for direct HPLC analysis method with UV detection. A stability indicating HPLC method with UV detection at $210 \mathrm{~nm}$ was reported for Gabapentin. . $^{13-14}$

The aim of present study was to develop a simple, rapid, accurate and precise HPLC method with UV detection. The method requires no extraction, no pre column derivetization step or no programmed linear gradient HPLC method. The method can be determined on simple HPLC with isocratic system, which is readily available in most analytical and pharmaceutical laboratories. The total analysis time is less than 10 minutes. The method was used successfully applied for determination of assay of Gabapentin capsule and tablets.

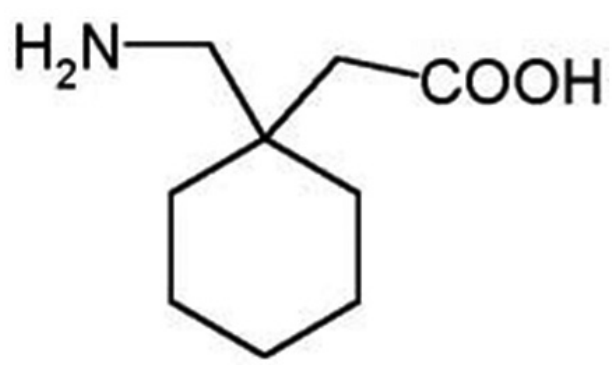

Figure.1 Chemical structure of 1-(aminomethyl)-cyclohexane acetic acid (Gabapentin)

\section{EXPERIMENTAL}

Materials and Methods

A sample of Gabapentin assigned purity $99.53 \%$ of pharmaceutical grade is received from Biocon Pharmaceuticals, Bangalore, India. Gabapentin capsule of strength $300 \mathrm{mg}$ and tablet of strength $100 \mathrm{mg}$ procured from the market. Ammonium dihydrogen orthophosphate of analytical grade purchased from Merck (Mumbai, India) HPLC grade methanol were purchased from Qualigens (Mumbai India). High purity water was prepared by Millipore milli Q plus purification system. (France)

Equipment

The M/S Shimadzu-Japan HPLC system with a photodiode array detector system (SPD -M20A) was used for the method development and forced degradation studies. The out put signal was monitored and processed using LC-solution (Shimadzu-Japan). The LC system used for method validation was Shimadzu HPLC LC- 2010 CHT with quaternary gradient pumps. The out put signal was monitored and processed using LC-solution (Shimadzu-Japan) on Pentium computer (Compaq-Mumbai).

Chromatographic conditions

Separation was achieved by using a strong cation exchange column, 250 $\mathrm{mm} \times 4.6 \mathrm{~mm}$ dia column with $10 \mu \mathbf{L}$ particle sizes. (Whatman-Maidstone, England). The isocratic mobile phase pumped at the rate of $1.0 \mathrm{~mL}$ min${ }^{1}$ comprised of 0.15 molar ammonium dihydrogen orthophosphate buffer in milli Q water adjusted the $\mathrm{pH}$ to 3.0 with orthophosphoric acid and methanol $60: 40(\mathrm{v} / \mathrm{v})$. The diluent used was methanol prepared daily and degassed by passing through $0.45 \mu \mathrm{m}$ Millipore filter and ultrasonication for $10 \mathrm{~min}$. The column temperature was maintained at $25^{\circ} \mathrm{C}$ with detection at $200 \mathrm{~nm}$. The injection volume was $10 \mu \mathrm{L}$. Prior to the injection of the drug solution, the column was equilibrated for 60 minutes.

Preparation of standard solution

The stock standard solution of drug substance $5 \mathrm{mg} / \mathrm{mL}$ was prepared using methanol as solvent.

Preparation of sample solution

To determine the content of Gabapentin, twenty capsules content were weighed and transferred into a clean and dry mortar. Then crushed and mixed well to prepare homogeneous mixture. A sample equivalent to $125 \mathrm{mg}$ of Gabapentin was taken in $25 \mathrm{~mL}$ volumetric flask with the aid of $15 \mathrm{~mL}$ methanol and soniccated for 10 minutes diluted to $25 \mathrm{~mL}$. $(5 \mathrm{mg} / \mathrm{mL})$. All the experiment was conducted in triplicate. The overlay chromatogram of placebo and drug substance are shown in fig.2. 


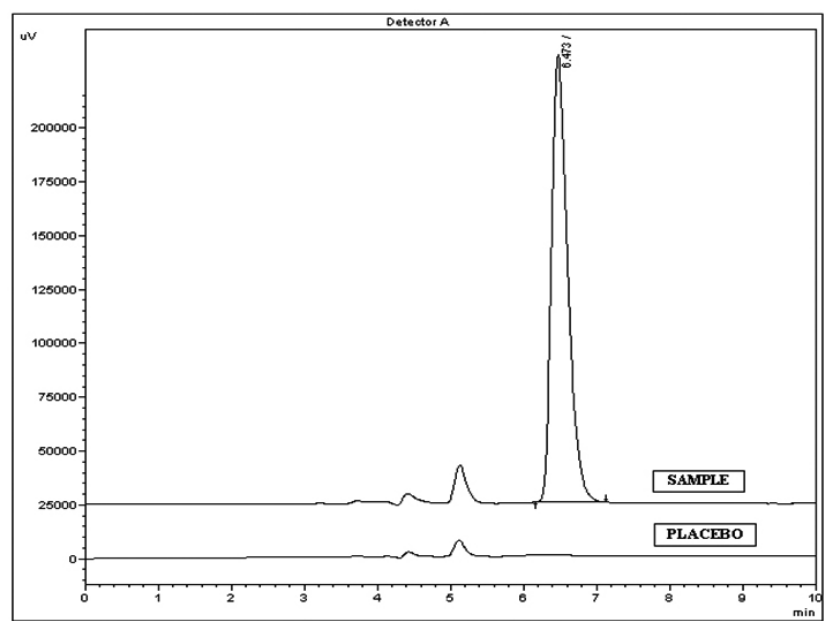

Figure 2. Overlay chromatograms of Gabapentin and placebo Chromatographic conditions:

Column: Whatman partisil SCX column. $10 \mu, 4.6$ x $250 \mathrm{~mm}$ Flow rate: $1 \mathrm{ml} / \mathrm{min}$

Detection: UV 200nm

Mobile phase: Buffer: Methanol 60:40 (v/v)

$0.15 \mathrm{M}$ Ammonium dihydrogen orthophosphate, $\mathrm{pH} 3.0$ adjusted with $\mathrm{H} 3 \mathrm{PO} 4$

Concentration: 5mg Gabapentin/ml

\section{Specificity}

In an attempt to develop a stability indicating assay method, the samples of placebo and capsule powder were subjected separately for following conditions. Acidic degradation using $5 \mathrm{~mL}$ of $2 \mathrm{~N} \mathrm{HCl}$, basic degradation using $5 \mathrm{~mL} 2 \mathrm{~N}$ $\mathrm{NaOH}$ solution, Oxidative degradation using $5 \mathrm{~mL}$ of $6 \%$ hydrogen peroxide solution. These conditions all exposed at $80^{\circ} \mathrm{C}$ for $6 \mathrm{~h}$. Photodegradation study was performed for the same samples by exposing them to artificial solar radiation of irradiation of $1,200 \mathrm{~K}$ lux of visible light and $200 \mathrm{~W} \mathrm{~h} \mathrm{~m}^{-2}$ of $\mathrm{UV}$ light by using photo stability chamber. Heat degradation was carried out by heating at $105^{\circ} \mathrm{C}$ for $24 \mathrm{~h}$. These solutions after appropriate dilutions $(5 \mathrm{mg} /$ $\mathrm{mL}$ ) with methanol (neutralization for the acidic and basic degradation) were injected in the chromatographic system.

\section{Method Validation}

Precision

Assay of method precision (intra-day precision) was evaluated by carrying out six independent assays of test sample of Gabapentin. (concentration 5 $\mathrm{mg} / \mathrm{mL}$ ) against qualified reference standard. The percentage of R.S.D. of six assay values obtained was calculated. The intermediate precision (interday precision) of the method was also evaluated using two different analysts, different HPLC systems and different HPLC columns in different days in the same laboratory.

Linearity

The standard calibration curves were prepared with five calibration over a concentration range of $2.5 \mathrm{mg} / \mathrm{mL}-7.5 \mathrm{mg} / \mathrm{mL}(2.5,4.0,5.0,6.0$ and 7.5 $\mathrm{mg} / \mathrm{mL}$ ) for Gabapentin. The data of peak area versus drug concentration were treated by linear least square regression analysis. The standard curves are evaluated intra- day and inter-day linearity. The range was the interval between the highest and lowest concentration. of analyte where acceptable linearity, precision and accuracy were obtained. Calibration standard solution of five levels was prepared daily by the stock solution $25 \mathrm{mg} / \mathrm{mL}$ in methanol to concentrations of $2.5,4.0,5.0,6.0$ and $7.5 \mathrm{mg} / \mathrm{mL}$ in methanol.

\section{Accuracy}

A study of recovery of Gabapentin from spiked placebo was conducted. Samples were prepared by mixing placebo with Gabapentin raw material equivalent to about $50,80,100,120$ and $150 \%$ of the assay nominal sample concentration. Sample solutions were prepared in triplicate for each spike level as described in the sample preparation. The percentage of recovery was calculated.

\section{Robustness}

To determine the robustness of the developed method, experimental conditions were purposely altered. One factor at a time was changed to estimate the effect. Thus, five replicate injections of standard solution were injected under each parameter and observed the change on the tailing factor for Gabapentin peak and the R.S.D. for peak area of Gabapentin. The flow rate of mobile phase was changed by $\pm 10 \%$ i.e. 0.9 to $1.1 \mathrm{~mL} \mathrm{~min}^{-1}$. The effect of $\mathrm{pH}$ of buffer in mobile phase was studied by varying $\pm 0.2 \mathrm{pH}$ units. The effect of column temperature was studied at 20 and $30^{\circ} \mathrm{C}$ instead of $25^{\circ} \mathrm{C}$. The effect of $\pm 10 \%$ of the organic phase composition (methanol) in mobile phase was studied by changing buffer and methanol composition by $64: 36(\mathrm{v} / \mathrm{v})$ and $56: 44(\mathrm{v} / \mathrm{v})$.

\section{Solution Stability and Mobile Phase Stability}

Stability solution of Gabapentin in the assay method (concentration $5 \mathrm{mg} /$ $\mathrm{mL}$ ) was carried out by leaving both the test solutions of sample and reference standard in tightly capped volumetric flasks at room temperature in a dark chamber for $72 \mathrm{~h}$. The same sample solution was assayed for $24 \mathrm{~h}$ interval up to the study period. The mobile phase stability was also carried out by assaying prepared sample (concentration $5 \mathrm{mg} / \mathrm{mL}$ ) solution against freshly prepared reference standard solution for $24 \mathrm{~h}$ interval for $72 \mathrm{~h}$. Mobile phase prepared was kept constant during the study period. The \% R.S.D. of assay of Gabapentin was calculated for the study period during mobile phase stability and solution stability experiments.

\section{RESULTS AND DISCUSSION}

\section{Method Development and Optimization}

The HPLC procedure was optimized with a view to develop a stability indicating assay method. In the first place the drug has low absorbtivity at normal UV range 220 to $380 \mathrm{~nm}$. It was found that the drug is having significant absorbance at $200-215 \mathrm{~nm}$. Hence $200 \mathrm{~nm}$ wavelength was selected. The Gabapentin is small highly polar molecule which can exist as cation, anion and zwitterions due to its acid. $\mathrm{pK}_{\mathrm{a}}$ of 3.7 and base $\mathrm{pKa}$ of 10.7. Initially we tried with ion pairing agent like heptane sulphonic acid and octane sulphonic acid using buffer and organic modifier on C18 column. As the desired result is not achieved on $\mathrm{C} 18$ column, strong cation exchange column bonded with phenyl sulphonic acid was used. Buffer ammonium dihydrogen phosphate improved the peak shape of the Gabapentin. When the mobile phase consisting 0.15 molar ammonium dihydrogen ortho phosphate buffer and methanol in the ratio $60: 40 \mathrm{v} / \mathrm{v}$ eluted the Gabapentin and retention time was about 6.5 min.[Fig 2] and well seperated between Gabapentin and its degradants with a flow rate of $1.0 \mathrm{~mL} \mathrm{~min}^{-1}$. As the related impurity was not used in the method, the Gabapentin in dosage form degraded up to $97 \%$ wherever possible and run on the system. All the degradants were well separated and no interference observed from any of the degradants under all stress condition.

\section{Method Validation}

\section{Precision}

Method repeatability (intra-day precision) was evaluated by assaying six samples, prepared as described in the sample preparation. The mean \% assay and percentage R.S.D. for assay values were found to be 99.7 and 0.2 $\%$, respectively, which is well within the acceptance criteria i.e. assay value should be between 97.0 and $103.0 \%$ and R.S.D. should be not more than $2.0 \%$. The intermediate precision (inter-day precision) was performed by assaying six samples prepared by different analyst, different HPLC system and different HPLC column in different days as described in the sample preparation. The mean $\%$ assay and percentage R.S.D. for assay values were found to be 99.4 and $0.1 \%$, respectively. The results of intra-day precision and inter-day precision were evaluated with respect to student's t- test and found that t-test was passed. The result shows that good precision of the method

Linearity

Linearity of the method confirmed by preparing Gabapentin standard curves for the analytical range of 2.5-7.5 mg/mL. Excellent correlation between analyte peak area and concentration of the drug was observed with $\mathrm{r}^{2} \geq 0.999$ for all standard curves. Precision and accuracy were established for drug substance from 2.5 to $7.5 \mathrm{mg} / \mathrm{mL}$. Therefore range for the method is $2.5-7.5 \mathrm{mg} / \mathrm{mL}$.

\section{Accuracy}

The percentage recovery of Gabapentin in pharmaceutical dosage forms ranged from 97 to $105 \%$ (Table I). 
Table I. Recovery results of Gabapentin in pharmaceutical dosage form.

\begin{tabular}{|lllcc|}
\hline $\begin{array}{l}\text { Spike } \\
\text { Level (\%) }\end{array}$ & $\begin{array}{c}\text { Average } \\
\text { 'mg' added }\end{array}$ & $\begin{array}{l}\text { Average } \\
\text { 'mg' found }\end{array}$ & $\begin{array}{c}\text { Mean \% } \\
\text { recovery }\end{array}$ & $\begin{array}{c}\text { Percentage } \\
\text { R.S.D }\end{array}$ \\
\hline 50 & 49.76 & 52.17 & 104.3 & 0.23 \\
80 & 80.0 & 81.69 & 102.1 & 0.08 \\
100 & 100.0 & 102.56 & 102.6 & 0.33 \\
120 & 120.0 & 117.11 & 97.6 & 0.27 \\
150 & 150.0 & 148.88 & 99.3 & 0.38 \\
\hline
\end{tabular}

\section{Robustness}

In all the deliberate varied chromatographic condition carried out i.e. flow rate, column temperature, $\mathrm{pH}$ of the buffer in mobile phase and organic phase composition in mobile phase, the tailing factor and the \% R.S.D. for the Gabapentin peak area from the five replicate injections of standard was found to be with in the acceptable limits, illustrating the robustness of the method (Table II).

Table II. Results of robustness study

\begin{tabular}{|c|c|c|c|}
\hline \multirow{2}{*}{ Parameter } & \multicolumn{3}{|l|}{ observed value } \\
\hline & Variation & $\begin{array}{l}\text { Tailing } \\
\text { factor }\end{array}$ & $\begin{array}{l}\text { RSD for } \\
\text { five injection } \\
\text { of standard (\%) }\end{array}$ \\
\hline Flow rate & $\begin{array}{l}0.9 \mathrm{~mL}^{-1} \\
1.1 \mathrm{~mL}^{-1}\end{array}$ & $\begin{array}{l}1.2 \\
1.3\end{array}$ & $\begin{array}{l}0.63 \\
0.24\end{array}$ \\
\hline Column temperature & $\begin{array}{l}20^{\circ} \mathrm{C} \\
30^{\circ} \mathrm{C}\end{array}$ & $\begin{array}{l}1.1 \\
1.0\end{array}$ & $\begin{array}{l}0.62 \\
0.44\end{array}$ \\
\hline $\mathrm{pH}( \pm 0.2$ units of the set $\mathrm{pH})$ & $\begin{array}{l}2.8 \\
3.2\end{array}$ & $\begin{array}{l}1.2 \\
1.1\end{array}$ & $\begin{array}{c}0.43 \\
0.42\end{array}$ \\
\hline $\begin{array}{r}\text { Mobile phase composition } \\
\text { Buffer: } \mathrm{Me} \\
\text { Buffer: } \mathrm{Me}\end{array}$ & $\begin{array}{l}\text { thanol(54:46) } \\
\text { thanol(66:34) }\end{array}$ & $\begin{array}{l}1.1 \\
1.1\end{array}$ & $\begin{array}{l}0.28 \\
0.97\end{array}$ \\
\hline
\end{tabular}

\section{Solution Stability and Mobile Phase Stability}

The R.S.D. of assay of Gabapentin during solution stability and mobile phase stability experiments was within $1 \%$. The solution stability and mobile phase stability experiments data confirms that sample solutions and mobile phase used during assay determination was stable up to $72 \mathrm{~h}$.

\section{Results of Forced Degradation Studies}

All the stressed samples prepared were injected into the HPLC system with photodiode array detector as per the described chromatographic conditions. Degradation was not observed in heat. But almost completely degraded in acid hydrolysis, base hydrolysis and oxidative conditions. Degradation was found to be partial in UV and light. All degradants peaks were resolved from Gabapentin . All the chromatograms of the stressed samples were evaluated for peak purity of Gabapentin using Shimadzu LC solution Software. In all the forced degradation samples impurity was not detected in the Gabapentin peak. The spectral homogeneity (Peak purity) $200-400 \mathrm{~nm}$ was determined in the forced degraded samples. The threshold was set at $\geq 0.990$. The peak purity and percent degradation (Table-III) for Gabapentin in capsule were demonstrated that the proposed LC method was able to separate Gabapentin from degradants generated during forced degradation studies. The chromatogram of oxidation condition was shown in figure 3 .

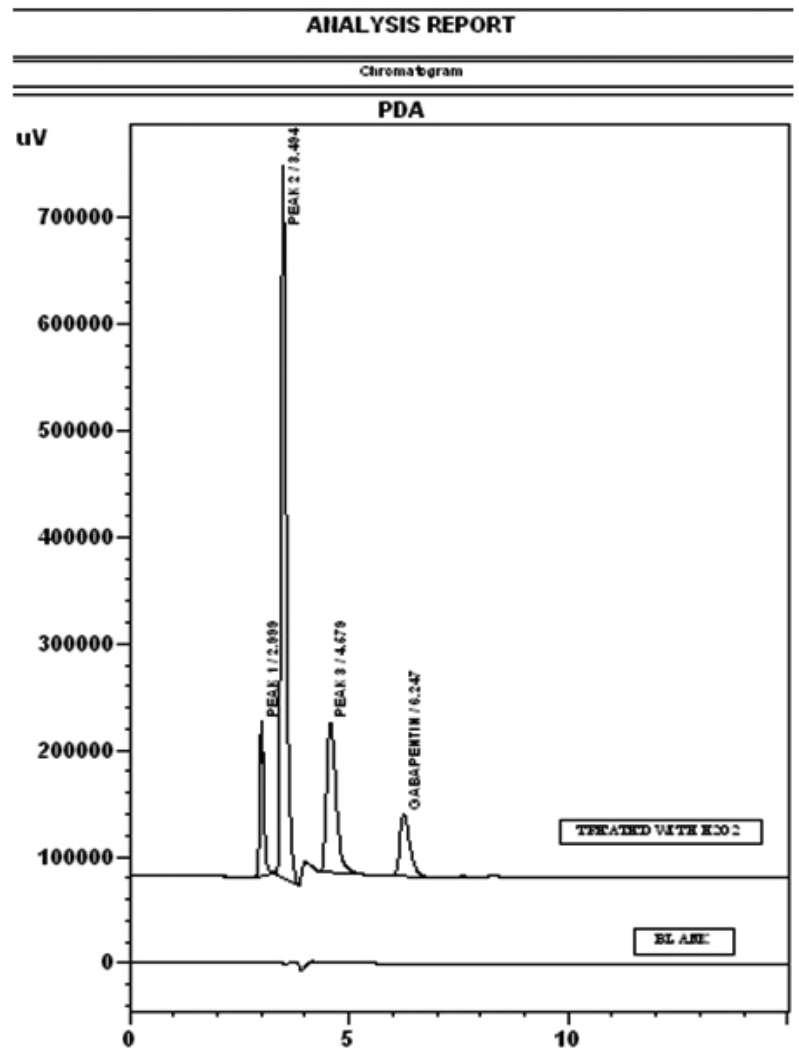

Figure 3. Typical Chromatograms of oxidation stressed gabapentin capsule test.

Chromatographic conditions:

Column: Whatman partisil SCX column. $10 \mu, 4.6$ x 250mm Flow rate: $1 \mathrm{ml} / \mathrm{min}$

Mobile phase: Buffer: Methanol 60:40 (v/v)

$0.15 \mathrm{M}$ Ammonium dihydrogen orthophosphate, $\mathrm{pH} 3.0$ adjusted with $\mathrm{H} 3 \mathrm{PO} 4$

Concentration: $5 \mathrm{mg}$ Gabapentin/ml

Detection: UV $200 \mathrm{~nm}$

The capsule sample stressed with $3 \% \mathrm{H} 2 \mathrm{O} 2$ solution at $80 \mathrm{oC}$ for $6 \mathrm{~h}$

Table III. Results of specificity.

\begin{tabular}{|c|c|c|c|}
\hline \multirow[t]{2}{*}{ Stress condition } & \multicolumn{3}{|l|}{ Drug product } \\
\hline & \%degradation & impurity & $\begin{array}{l}\text { peak purity } \\
\text { index }\end{array}$ \\
\hline Digested with $2 \mathrm{~N} \mathrm{HCl}$ solution for about $6 \mathrm{~h}$ at $80^{\circ} \mathrm{C}$ & $95 \%$ & ND & 0.9999 \\
\hline Digested with $2 \mathrm{~N} \mathrm{NaOH}$ solution for about $6 \mathrm{~h}$ at $80^{\circ} \mathrm{C}$ & $97 \%$ & ND & 0.9995 \\
\hline Digested with $6 \% \mathrm{H} 2 \mathrm{O} 2$ solution for about $6 \mathrm{~h}$ at $80^{\circ} \mathrm{C}$ & $90.5 \%$ & ND & 1.0000 \\
\hline Exposed to Visible light for about $1200 \mathrm{~K} \mathrm{lux}$ & $2.0 \%$ & ND & 1.0000 \\
\hline \multicolumn{4}{|l|}{ Exposed to UV light both at shorter and longer wave length } \\
\hline- for $200 \mathrm{~W} \mathrm{~h} \mathrm{~m}^{-2}$ & $2.0 \%$ & ND & 0.9999 \\
\hline Dry heated for about $24 \mathrm{~h}$ at $105^{\circ} \mathrm{C}$ & Nil & ND & 1.0000 \\
\hline
\end{tabular}

\section{Analysis of marketed products:}

The validated method was used in the analysis of two Gabapentin drug products from two different manufacturer. One is Gabapentin tablet of strength $100 \mathrm{mg}$ and another one is Gabapentin capsule of strength $300 \mathrm{mg}$. In both cases assay obtained is more than $98 \%$ and no interference of impurity peak observed in Gabapentin peak. 


\section{CONCLUSION}

The developed LC method is sensitive, accurate, rugged and selective for the determination of Gabapentin in a capsule formulation. Application of this method for the analysis in capsule shows that neither the degradation products nor the excipients, including the preservatives interfere with the analytical determination. This indicates that the proposed method could be used as a stability indicating method for the determination of Gabapentin either in bulk powder or in pharmaceutical formulations.

\section{ACKNOWLEDGMENTS}

The authors wish to thank the Chairman of Maulana Azad Education Trust and Principal Dr. M. H. Dehghan for encouragement. We are greatful to M/S Biocon Pharmaceuticals, Bangalore for providing gift samples of Gabapentin and Prof. D.B. Shinde, UDCT, Dr. B. A.M. University, Aurangabad, for helpful discussions.

\section{REFERENCES}

1. M. C. Walker, P. N. Patsalos, Pharm. Ther. 67, 351-384, (1995).

2. C.P. Taylor, T. Angelotti , E. Fauman, Epilepsy Res.,73,137-150,(2007).

3. N.B. Finnerup, H. Gottrup, T.S.Jensen, Exp.Opin.Pharmacother.3, 14111420, (2002).
4. T.A. Vermeji, P.M. Edelbroek, Journal of Chromatogr. B: Biomed. Appl 810, 297-303, (2004).

5. Z. Zhu, L.Neirinck, Journal of Chromatogr. B: Biomed. Appl. 779(2), 307$312,(2004)$

6. N.V.S. Ramkrishna, K.N. Vishwottam, M. Koteshwara, Manoj, M.Santosh, J. Chidambara, B. Sumatha, Journal of Chromatogr. B: Biomed, Anal.27, 253-260, (2002).

7. H. Hengy, E.U.Kolle, J. Chromatogr, 341, 473-478, (1985).

8. S.Y. Chang, F. Y. Wang, J. Chromatogr. B: Biomed. Appl.799, 265-270 (2004).

9. Sagirli O., Cetin S.M., Onal A, J. Pharm. Biomed. Anal., 42, 618-624, (2006).

10. F. Belal, H.Abdine, H. Al-Majed, N.Y. Khalil, J. Pharm. Biomed. Anal., 27, 253-260, (2002).

11. E Souri, H Jalalizadeh, A Shafiee., Chem Pharm Bull (Tokyo), 55(10),14271430, (2007).

12. Ratnaraj, Neville, Patsalos, N.Philip , Therapeutic Drug Monitoring, 20(4), 430-434, (1998).

13. Ciavarella, A.B. Gupta, A.Sayeed, V.A. Khan, M.A., Faustino J. of Pharmaceutical and Biomedical analysis , 46(5),1647-1653,(2007).

14. A.Gupta, Ciavarella, A.B. Sayeed, V.A. Khan, M.A., Faustino J. of Pharmaceutical and Biomedical analysis, 43,181-186, (2008). 